\title{
Immatures of Wyeomyia (Tryamyia) aporonoma (Diptera: Culicidae) Collected in Artificial Breeding in the South Brazil
}

\author{
Allan Martins da Silva ${ }^{\circledR}{ }^{\bowtie}$, Roderlei Araújo ${ }^{1}$ \& Enéas Cordeiro Souza Filho²
}

1. Laboratório Central, Secretaria de Estado da Saúde do Paraná, PR, Brasil, e-mail: allan.silva@sesa.pr.gov.br (Autor para correspondência ${ }^{\varpi}$ ), roderleiaraujo@sesa.pr.gov.br. 2. Divisão de Doenças Transmitidas por Vetores, Secretaria de Estado da Saúde do Paraná, PR, Brasil. e-mail: eneasfilho@sesa.pr.gov.br.

\section{EntomoBrasilis 9 (2): 140-142 (2016)}

Abstract. Reported is a date of immature forms of Wyeomyia (Triamyia) aporonoma Dyar \& Knab in artificial container, associated with Aedes (Stegomyia) albopictus (Skuse) is provided. The record was made during entomological survey at the municipality of Matinhos, littoral of the state of Paraná, Brazil.

Keywords: Culicinae; Entomological Surveillance; Mosquitoes; Sabethini; Vector Ecology.

\section{Imaturos de Wyeomyia (Tryamyia) aporonoma (Diptera: Culicidae) Coletados em Criadouro Artificial no Sul do Brasil-}

Resumo. Relata-se o encontro de formas imaturas de Wyeomyia (Triamyia) aporonoma Dyar \& Knab em recipiente artificial, associado ao Aedes (Stegomyia) albopictus (Skuse), durante inquérito entomológico no município Matinhos, litoral do estado do Paraná, Brasil.

Palavras-chaves: Culicinae; Ecologia de Vetores; Mosquitos; Sabethini; Vigilância Entomológica.

$\mathbb{M}$ osquitoes belonging to the genus Wyeomyia (Diptera: Culicidae) are widespread in the American Continent They occur in different biomes of the Nearctic and Neotropical regions. They find, in the forest environment, appropriate conditions for reproduction, shelter, food and places where their immatures can develop.

In the forest, Wyeomyia females oviposit in aquatic microecosystems known as phytotelmata, which result from the accumulation of water in certain structures of terrestrial plants. Bromeliads, Araceae, bracts, bamboo internodes, tree holes, fruit peels and fallen leaves, form the natural phytotelmata that house the immature forms of Wyeomyia (Consoli \& LourençoDE-Oliveira 1994; Forattini 2002).

It is not known exactly where in anthropic environments Wyeomyia females oviposit. According to ForATrini et al. (1990), anthropic areas adjacent to the originally favored sites may harbor niches that can be occupied by sylvatic mosquitoes. Silva et al. (2004), for instance, found immature forms of Wyeomyia spp. on the bromeliads of an area impacted by mining in the municipality of Paranaguá, Brazil, demonstrating that these mosquitoes are able to colonize breeding sites in anthropic environments.

It is rare to find Wyeomyia spp. in artificial containers in the American continent, but there have been a few reports. In Costa Rica, Wyeomyia (Triamyia) aporonoma Dyar \& Knab immatures were found in a sink with church holy water (Кuмm et al. 1940). In French Guyana, immatures of Wyeomyia argenteorostris (Bonne-Wepster \& Bonne) were collected from small tanks (Floch \& Abonnenc 1947). In Panama, Wyeomyia (Wyeomyia) arthrostigma (Lutz) immatures were found colonizing abandoned cans (ARNETT 1949) and in Tobago the species was collected from artificial containers (CHADEE et al. 1984; CHADDE 1990). In Brazil were collected eggs $W y$. (Tra.) aporonoma in ovitraps traps installed in four different Paraíba Valley's microregions, state of São Paulo (SANTos-Neto \& MARques 1996).

Wyeomyia (Triamyia) aporonoma is widely distributed in 18 countries of the Neotropical region, from Mexico to Argentina, including Brazil (Walter Reed Biosystematics Unit. Available at: http://www.wrbu.org/). In the state of Paraná Wy. (Tra.) aporonoma has been recorded from Cambará, Londrina, Paranaguá and Foz do Iguassu (Lane \& CERQueIra 1942; GuIMARÃes et al. 2003).

In Forests Wy. (Tra.) aporonoma are diurnal, and occur near the ground, where they feed on the blood of wild animals and occasionally human blood (GALINDO et al. 1955; TRAPIDO et al. 1955; AitKen 1956; Forattini et al. 1968; RoberTs et al. 1981; GUIMARÃEs et al. 1985). At least some species of Wyeomyia seem to prefer natural containers in shady places in the forest ground, such as Araceae and Bromeliaceae. This may influence the choice of oviposition sites that are protected from the sun in the urban environment.

However, little is known about the diversity patterns of mosquitoes in urban areas and their epidemiological implications. The epidemiological relevance of Wyeomyia lies in the maintenance of wild arboviruses. In Trinidad, the virus Kairi (Orthbunyavirus) was obtained from Wy. (Tra.) aporonoma and Wyeomyia spp. (ANDERson et al. 1960). However, at the Yucatán Peninsula, in Mexico, there is evidence that this virus circulates among domestic animals and humans (FARFAN-Ale et al. 2009; BlitVICH et al. 2012).

The virus Kairi also occurs in tropical and subtropical regions of South America, where it is potentially infectious to humans and animals, both domestic and wild. In Brazil, the virus has been 
T four found in natural hosts such as monkeys and Aedini mosquitoes (Woodal 1967; Causey et al. 1961). In Argentina, it was detected in horses and humans (CALISHER et al. 1988; TAURO et al. 2009).

This is the first report of Wyeomyia colonizing artificial breeding sites in the South Brazil. On 07.29.2015, during entomological survey of the municipality of Matinhos, littoral of the state of Paraná, 66 immature mosquitoes were collected from water accumulated in two tires, using a fine white-mesh net $(10 \mathrm{~cm}$ in diameter and $15 \mathrm{~cm}$ in length) with short cable. Of these, 16 were $W y$. (Tra.) aporonoma larvae and the other 50 (46 larvae and four pupae) were Aedes (Stegomyia) albopictus (Skuse). The tires were in the shade, in the backyard of an educational center at an urban area $\left(25^{\circ} 49,87^{\prime} \mathrm{S} ; 48^{\circ} 32,97^{\circ} \mathrm{W}\right.$ (DDM) - approximate elevation 7 meters above sea level and 450 meters far from the forest), and were being used to decorate a fern, popularly known as samambaia (Figure 1).

The identification of Wy. (Tra.) aporonoma was based on morphological characters of the immatures following LANE \& Cerqueira (1942) and Lane (1953), with some variations: head seta \# 7 double or triple; abdomen - four dorsal setae on siphon (three simple and one preapical double or triple). Inclusion of Wy. aporonoma subgenus Triamyia was based on MotTa et al. (2007). The immature forms of Ae. (Stg.) albopictus were identified based on the key by ForatTinI (2002). The mosquito name abbreviations follow REINERT (2009).

Voucher material is deposited at the entomological collection Padre Jesus Santiago Moure (Diptera), "Universidade Federal do Paraná”, Curitiba, Paraná, Brazil (DZUP), accession numbers DZUP 249.277 to 249.279, [Wy. (Tra.) aporonoma], and DZUP 249.280 to 249.282 , [Ae. (Stg.) albopictus].

The fact that immature forms of Wy. (Tra.) aporonoma were found together with Ae. (Stg.) albopictus, a synanthropic species, suggests that the former can be able to occupy the same types of artificial recipients abandoned in anthropic environments. In Florida, Wyeomyia (Wyeomyia) vanduzeei Dyar \& Knab immatures was found in Bromeliaceae with Aedes (Stegomyia) aegypti (Linnaeus) or Culex (Culex) quinquefasciatus Say (Hribar et al. 2004).

On a last note, the record of immatures of Wy. (Tra.) aporonoma in artificial containers brings up some questions: is this an accidental finding? Do females of Wy. (Tra.) aporonoma find new shelters and food sources in the urban areas of Parana's littoral? These questions may possibly open up new perspectives in the study of the adaptive potential of the species in the anthropic environment.

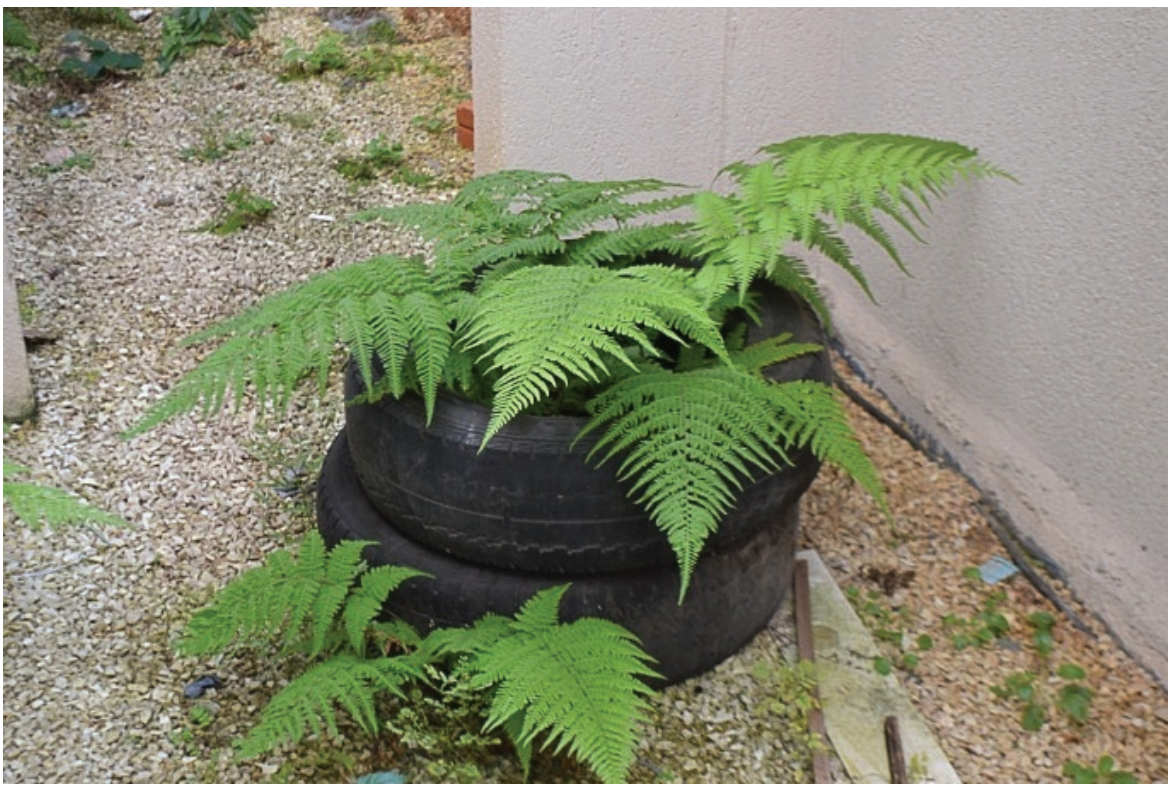

Figure 1. Collection site of immature forms Wyeomyia (Triamyia) aporonoma e Aedes (Stegomyia) albopictus, Matinhos city, state of Paraná, Brazil (Silva, A.M.).

\section{ACKNOWLEDGEMENTS}

We thank Ilda Nagafuti Diretora of the " $1^{\text {a }}$ Regional de Saúde de Paranaguá", "Secretaria de Estado da Saúde do Paraná", for her support during this work. We also thank Prof. Dr. Mário Antônio Navarro da Silva da "Universidade Federal do Paraná", for accepting the voucher material into the entomological collection of DZUP.

\section{REFERENCES}

Aitken, T.H.G., 1956. Entomological aspects of the Trinidad virus research program. Proceedings of the Tenth International Congress of Entomology, 3: 573-580.

Anderson, C.R., T.H.G. Aitken, J.P. Speace \& W.C. Downs, 1960. Kairi virus, in new virus from Trinidad forest mosquitoes. American Journal of Tropical Medicine and Hygiene, 9: 7072.
Arnett, R.H., 1949. Notes on the distribution, habits, and habitats of some Panama culicines (Diptera: Culicidae). Journal of the New York Entomological Society, 57: 233-251.

Blitvich, B.J., R. Saiyasombat, L.G. Talavera-Aguilar, J.E. GarciaRejon, J.A. Farfan-Ale, C. Machain-Williams \& M.A. LoroñoPino, 2012. Orthobunyavirus Antibodies in Humans, Yucatan Peninsula, Mexico. Emerging Infectious Diseases, 18: 16291632. DOI: http://dx.doi.org/10.3201/eid1810.120492.

Calisher, C.H., J.G. Oro, R.D. Lord, M.S. Sabattini \& N. Karabatsos, 1988. Kairi virus identified from a febrile horse in Argentina. American Journal of Tropical Medicine and Hygiene, 39: 519-521.

Causey, O.R., C.E. Causey, O.M. Maroja \& D.G. Macedo, 1961. The isolation of arthropod-born viruses including members of two hitherto undescribed serological groups, in the Amazon Region of Brazil. American Journal of Tropical Medicine and Hygiene, 10: 227-249.

Chadee, D.D., 1990. Aedes aegypti surveillance in Tobago, West Indies (1983-88). Journal of the American Mosquito Control Association, 6: 148-150. 
Chadee, D.D., N.K. Connell, A. Le Maitre \& S.B. Ferreira, 1984. Surveillance for Aedes aeqypti in Tobago, West Indies (19801982). Mosquito News, 44: 490-492.

Consoli, R.A.G.R. \& R. Lourenço-de-Oliveira, 1994. Principais mosquitos de importância sanitária no Brasil. Rio de Janeiro, Fundação Oswaldo Cruz, 228 p.

Farfan-Ale, J.A., M.A. Lorono-Pino, J.E. Garcia-Rejon, E. Hovav, A.M. Powers, M. Lin, K.S. Dorman, K.B. Platt, L.C. Bartholomay, V. Soto, B.J. Beaty, R.S. Lanciotti \& B.J. Blitvich, 2009. Detection of RNA from a novel West Nile-like virus and high prevalence of an insect-specific flavivirus in mosquitoes in the Yucatan Peninsula of Mexico. American Journal of Tropical Medicine and Hygiene, 80: 85-95.

Floch, H. \& E. Abonnenc, 1947. Distribution des moustiques du genre Culex en Guyane Française. Archives de l'Institut Pasteur de la Guyane Française, 146: 9.

Forattini, O.P., 2002. Culicidologia médica, Identificação, Biologia, Epidemiologia, vol. II. São Paulo, Editora da Universidade de São Paulo, 864 p.

Forattini, O.P., A.C. Gomes, J.D. Santos, I. Kakitani \& D. Marucci, 1990. Freqüência ao ambiente humano e dispersão de mosquitos Culicidae em área adjacente à Mata Atlântica primitiva da planície. Revista de Saúde Pública, 24: 101-107. DOI: http://dx.doi.org/10.1590/s003489101990000200004 .

Forattini, O.P., O.S. Lopes \& E.X. Rabello, 1968. Investigações sôbre o comportamento de formas adultas de mosquitos Silvestres no Estado de São Paulo, Brasil. Revista de Saúde Pública, 2: 111-173. DOI: http://dx.doi.org/10.1590/s003489101968000200002.

Galindo, P., S.J. Carpenter \& H.A. Trapido, 1955. Contribution to the Ecology and Biology of Tree Hole Breeding Mosquitoes of Panama. Annals of the Entomological Society of America, 48: 158-164. DOI: http://dx.doi.org/10.1093/aesa/48.3.158.

Guimarães, A.É., M. Arlé \& R.N.M. Machado, 1985. Mosquitos no Parque Nacional da Serra dos Órgãos, estado do Rio de Janeiro, Brasil. II. Distribuição vertical. Memórias do Instituto Oswaldo Cruz, 80: 171-185. DOI: http://dx.doi.org/10.1590/s0074-02761985000200008.

Guimaraes, A.É., C.M. Lopes, R.P. Mello \& J. Alencar, 2003. Ecologia de mosquitos (Diptera, Culicidae) em áreas do Parque Nacional do Iguaçu, Brasil: 1 - Distribuição por hábitat. Cadernos de Saúde Pública, 19: 1107-1116. DOI: http://dx.doi.org/10.1590/s0102-311x2003000400032.

Hribar, L.J., J.J. Vlach, D.J. Demay, S.S. James, J.S. Fahey \& E.M. Fussell, 2004. Mosquito larvae (Culicidae) and other Diptera associated with containers, storm drains, and sewage treatment plants in the Florida Keys, Monroe County, Florida. Florida Entomologist, 87: 199-203. DOI: http://dx.doi.org/10.1653/0015-4040(2004)087[0199:mlca od]2.0.co;2.

Kumm, H., W. Komp \& H. Ruiz, 1940. The mosquitoes of Costa Rica. American Journal of Tropical Medicine and Hygiene, 20: 385-422.

Lane, J., 1953. Neotropical Culicidae, vol. II. São Paulo, Universidade de São Paulo, 1.112 p.

Lane, J. \& N.L. Cerqueira, 1942. Os Sabetíneos da América (Diptera, Culicidae). Arquivos de Zoologia do Estado de São Paulo, III: 473-849.

Motta, M.A., R. Lourenço-de-Oliveira \& M.A.M. Sallum, 2007. Phylogeny of genus Wyeomyia (Diptera: Culicidae) inferred from morphological and allozyme data. The Canadian Entomologist, 139: 1-37. DOI: http://dx.doi.org/10.4039/ no6-088.

Reinert, J.F., 2009. List of abbreviations for currently valid generic-level taxa in family Culicidae (Diptera). European Mosquito Bulletin, 27: 68-76.

Roberts, D.R., A.L. Hoch, N.E. Peterson \& F.P. Pinheiro, 1981. Programa multidisciplinario de vigilancia de las enfermedades infecciosas en zonas colindantes con la carretera transamazonica en Brazil. IV. Estudio entomológico. Boletín de la Oficina Sanitaria Panamericana, 91: 379-400.

Santos-Neto, L.G. \& C.C.A. Marques, 1996. Sobre ovos de mosquitos (Diptera, Culicidae) que colonizam recipientes artificiais. Revista Brasileira de Entomologia, 40: 17-20. DOI: http://dx.doi.org/10.1590/s0073-47212004000100011.

Silva, A.M., V. Nunes \& J. Lopes, 2004. Culicídeos associados a entrenós de bambu e bromélias, com ênfase em Aedes (Stegomyia) albopictus (Diptera, Culicidae) na Mata Atlântica, Paraná, Brasil. Iheringia. Série Zoologia, 94: 6366.

Tauro, L.B., F.L. Almeida \& M.S. Contigiani, 2009. First detection of human infection by Cache Valley and Kairi viruses (Orthobunyavirus) in Argentina. Transactions of the Royal Society Tropical Medicine and Hygiene, 103: 197-199. DOI: http://dx.doi.org/10.1016/j.trstmh.2008.09.004.

Trapido, H., P. Galindo \& S.J. Carpenter, 1955. A survey of forest mosquitoes in relation to sylvan yellow fever in Panama isthmian area. American Journal of Tropical Medicine and Hygiene, 4: 525-542.

Woodall, J.P., 1967. Vírus research in Amazônia. Atas Simpósio Sobre Biota Amazônica, 6: 31-63.

\section{Received in: 30.i.2016}

Accepted in: $07 . v .2016$

\section{Suggestion citation:}

Silva, A.M. da, R. Araújo \& E.C. Souza Filho, 2016. Immatures of Wyeomyia (Tryamyia) aporonoma (Diptera: Culicidae) Collected in Artificial Breeding in the South Brazil. EntomoBrasilis, 9 (2): 140-142.

Available on: doi:10.12741/ebrasilis.v9i2.588
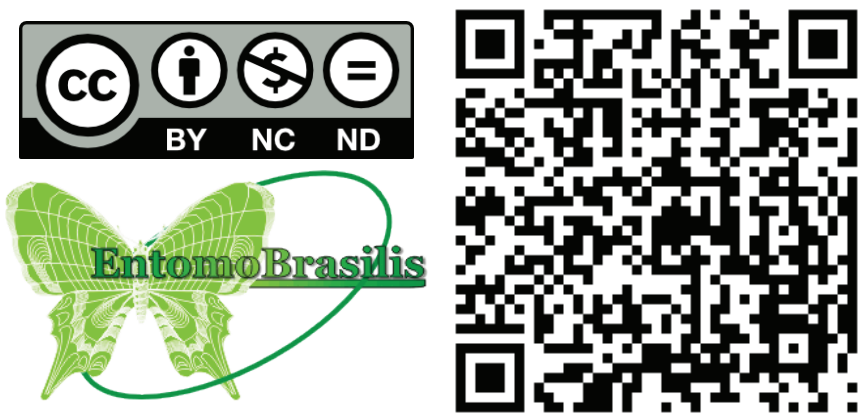